\title{
PENYIMPANGAN STRUKTUR FRASA BAHASA INDONESIA PADA SPANDUK DAN PAPAN NAMA DI KABUPATEN BANTUL INDONESIAN IRREGULARITIES PHRASE STRUCTURE AT THE BANNERS AND SIGNAGE IN THE DISTRICT BANTUL
}

\author{
Aji Prasetyo \\ Balai Bahasa Daerah Istimewa Yogyakarta \\ Jalan I Dewa Nyoman Oka 34, Kotabaru, Gondokusuman, Daerah Istimewa Yogyakarta \\ ajiprasetyo2009@gmail.com
}

\begin{abstract}
Language plays an important role in the communication process. Language used in outdoor media, such as hotel signage, store signage, and banners. The author still find much errors, particularly the structure of the writing of a group of words or phrases in the banner and the signage. The theory used in this study is diterangkan-menerangkan legal norms $(D-M)$, while the methodological approach used is descriptive qualitative approach. Data collection is performed using the method of direct observation (observation), technical notes, and documentation. Data analysis was performed having regard to the various aspects and types of errors. The results of the data analysis presented informal presentation method that is the presentation without the use of a particular sign or symbol. The results obtained, namely (1) the error occurred in the consumer's attention or community efforts, (2) the error occurred because the structure of phrases used are considered more prestigious, and (3) the error occurred because of the use of the word uptake is more prevalent in society.
\end{abstract}

Keywords: banner, signage, structure of phrases, language errors

\begin{abstract}
Abstrak
Bahasa memainkan peran penting dalam proses komunikasi. Bahasa dapat digunakan di semua tempat, termasuk pada media luar ruang, seperti papan nama hotel, papan nama toko, dan spanduk. Penulis masih menemukan banyak kesalahan, khususnya penulisan struktur kelompok kata atau frasa pada spanduk dan papan nama tersebut. Teori yang digunakan dalam penelitian ini ialah kaidah hukum diterangkan-menerangkan (D-M), sedangkan pendekatan metodologis yang digunakan adalah pendekatan deskriptif kualitatif. Pengumpulan data dilakukan dengan menggunakan metode observasi langsung, catatan teknis, dan dokumentasi. Analisis data dilakukan dengan memerhatikan berbagai aspek dan tipe kesalahannya. Hasil analisis data disajikan dengan metode penyajian informal, yaitu penyajian tanpa mengunakan tanda atau lambang tertentu. Hasil yang diperoleh, ialah (1) kesalahan itu terjadi dalam upaya perhatian konsumen atau masyarakat, (2) kesalahan itu terjadi karena struktur frasa yang digunakan dianggap lebih bergengsi, dan (3) kesalahan itu terjadi disebabkan pemakaian kata serapan tersebut lebih umum di masyarakat.
\end{abstract}

Kata kunci: spanduk, papan nama, struktur frasa, kesalahan bahasa

\section{Pendahuluan}

Saat ini, masih sering ditemukan spanduk dan papan nama yang salah dalam menggunakan bahasa Indonesia. Disadari atau tidak, penulisan kata pada spanduk dan papan nama seringkali tidak tepat dalam penggunaannya sehingga dapat membingungkan pembaca dalam memahami kalimatnya. Masyarakat biasanya tidak memperhatikan apakah tulisannya sudah sesuai dengan aturan atau belum, yang diperhatikan hanya tujuan dan maksudnya tersampaikan. Selain itu, ketidakpahaman penggunaan kaidah tata bahasa dapat menjadi penyebab kesalahan penulisan di spanduk dan papan nama. Banyak 
juga ditemukan penggunaan kata yang tidak baku dan tidak sesuai dengan kaidah ejaan.

Kesalahan penulisan pada kain rentang dan papan nama, khususnya di Kabupaten Bantul masih banyak ditemukan. Olehkarenaitu, penulis melakukan penelitian mengenai kesalahan penulisan struktur kelompok kata atau frasa pada kain rentang dan papan nama. Menulis pada kain rentang dan papan nama sebenarnya merupakan suatu keterampilan berbahasa yang dipergunakan untuk berkomunikasi secara tidak langsung. Namun, hasil pengamatan menunjukkan bahwa penulisan kain rentang dan papan nama di Kabupaten Bantul belum semuanya mematuhi kaidah tata bahasa Indonesia, khususnya struktur kata. Beberapa kain rentang dan papan nama masih salah dalam penulisan struktur katanya, yaitu tidak mengikuti hukum D-M (diterangkan-menerangkan). Sebagai contoh, kita biasa membaca papan nama atau kain rentang yang berpola M-D, seperti prima swalayan, fotokopi mawar, Yolanizam fasbion branded, mimi laundry, dan sebagainya.

Dengan demikian, kita juga perlu memahami undang-undang yang berhubungan dengan pemakaian bahasa Indonesia pada media luar ruang seperti berikut ini. Bahasa Indonesia yang dinyatakan sebagai bahasa resmi negara dalam Pasal 36 Undang-Undang Dasar Negara Kesatuan Republik Indonesia Tahun 1945 bersumber dari bahasa yang diikrarkan dalam Sumpah Pemuda tanggal 28 Oktober 1928 sebagai bahasa persatuan yang dikembangkan sesuai dengan dinamika peradaban bangsa. Hal tersebut tercantum dalam Pasal 25 ayat (1) Undang-Undang Republik Indonesia Nomor 24 Tahun 2009 tentang Bendera, Bahasa, dan Lambang Negara, serta Lagu Kebangsaan.

Bahasa Indonesia sebagaimana dimaksud pada ayat (1) tersebut berfungsi sebagai jati diri bangsa, kebanggaan nasional, sarana pemersatu berbagai suku bangsa, serta sarana komunikasi antardaerah dan antarbudaya daerah. Bahasa Indonesia sebagai bahasa resmi negara sebagaimana dimaksud pada ayat (1) juga berfungsi sebagai bahasa resmi kenegaraan, pengantar pendidikan, komunikasi tingkat nasional, pengembangan kebudayaan nasional, transaksi dan dokumentasi niaga, serta sarana pengembangan dan dan pemanfaatan ilmu pengetahuan, teknologi, seni, dan bahasa media massa.

Pasal 36 ayat (3) Undang-Undang Republik Indonesia Nomor 24 Tahun 2009 tentang Bendera, Bahasa, dan Lambang Negara, serta Lagu Kebangsaan mengatur bahwa bahasa Indonesia wajib digunakan untuk nama bangunan atau gedung, jalan, apartemen atau permukiman, perkantoran, kompleks perdagangan, merek dagang, lembaga usaha, lembaga pendidikan, organisasi yang didirikan atau dimiliki oleh warga negara Indonesia atau badan hukum Indonesia. Selanjutnya, pada Pasal 37 ayat (1) diatur bahwa bahasa Indonesia wajib digunakan dalam informasi tentang produk barang atau jasa produksi dalam negeri atau luar negeri yang beredar di Indonesia, ayat (2) diatur bahwa informasi sebagaimana dimaksud pada ayat (1) dapat dilengkapi dengan bahasa daerah atau bahasa asing sesuai dengan keperluan.

Pasal 38 ayat (1) dalam undang-undang tersebut diatur bahwa bahasa Indonesia wajib digunakan dalam rambu umum, penunjuk jalan, fasilitas umum, spanduk, dan alat informasi lainnya yang merupakan pelayanan umum. Selanjutnya, pada ayat (2) pasal tersebut diatur bahwa penggunaan bahasa Indonesia sebagaimana dimaksud pada ayat 
(1) dapat disertai bahasa daerah atau bahasa asing jika dipandang perlu. Ketentuan lebih lanjut mengenai penggunaan bahasa Indonesia sebagaimana yang dimaksud dalam undangundang diatur dalam Peraturan Presiden.

Berdasarkan uraian singkat latar belakang masalah di atas, dalam penelitian ini dapat dirumuskan permasalahan sebagai berikut.

a. Bagaimanakah bentuk-bentuk penyimpangan struktur kata bahasa Indonesia pada penulisan media luar ruang yang ada di wilayah Kabupaten Bantul?

b. Bagaimana analisis terhadap bentukbentuk penyimpangan struktur kata bahasa Indonesia pada penulisan media luar ruang yang ada di wilayah Kabupaten Bantul? Berdasarkan permasalahan tersebut, penelitian ini bertujuan sebagai berikut.

a. Menunjukkan bentuk-bentuk penyimpangan struktur kata bahasa Indonesia pada penulisan spanduk dan papan nama yang ada di wilayah Kabupaten Bantul.

b. Menganalisis bentuk-bentuk penyimpangan struktur kata bahasa Indonesia pada penulisan spanduk dan papan nama yang ada di wilayah Kabupaten Bantul.

Penelitian ini diharapkan dapat memberikan manfaat, baik bagi peneliti maupun pemerintah Kabupaten Bantul sebagai tempat penelitian.

a. Bagi peneliti, penelitian ini dapat bermanfaat untuk mengaplikasikan teori-teori kesalahan berbahasa dan mengembangkan ilmu pengetahun kebahasaan.

b. Bagi Pemerintah Kabupaten Bantul, penelitian ini dapat digunakan sebagai upaya perbaikan dalam rangka penggunaan dan penulisan yang sesuai dengan kaidah bahasa Indonesia yang baik, benar, dan tepat.

\section{Landasan Teori}

Hukum D-M (diterangkan-menerangkan) merupakan sebuah istilah yang dimunculkan oleh almarhum Sutan Takdir Alisjahbana (STA). Hukum D-M itu sendiri memang menjadi salah satu sifat utama bahasa Indonesia. Sebuah frasa atau kelompok kata terdiri atas unsur utama yang diikuti oleh unsur penjelas. Ada juga bentuk susunan sebaliknya, yaitu M-D, tetapi jumlahnya terbatas. Konstituen pembentuk frasa itu pun bermacam-macam, dapat nomina $(\mathrm{N})$, verba (V), adjektiva (Adj), pronomina (Pron), dan sebagainya. Kita lihat contoh berikut ini:

$\mathrm{NN}$ : vas bunga

NAdv: nasi kemarin

NPron: buku saya

NFrPrep: vila di puncak

NAdj: rumah mewah

VAdv: pergi lama

NPron: meja ini

NV: rumah makan

Kita perhatikan contoh di atas, baik kata pertama (yang diterangkan) maupun kata kedua (yang menerangkan), frasa tersebut terdiri atas kelas kata nomina, verba, adjektiva, dan sebagainya. Selain itu, frasa tersebut terdiri atas kata-kata sederhana (simple word) dan dapat juga terdiri atas kata-kata turunan (complex words), misalnya, pertimbangkan hati nurani, ketenangan pikiran, kesederhanaan dalam penampilan.

Konstituen menerangkan yang terdiri atas adverbia, frasa preposisi, dan numeralia terletak mendahului konstituen utama yang diterangkan, misalnya, belum dewasa, sudah pergi, di pasar, dari sekolah, lima orang, tiga buah jeruk. Arti atau makna yang ditimbulkan oleh paduan kedua unsur frasa itu dapat bermacam-macam seperti terlihat pada contoh-contoh berikut.

NV: rumah makan, kamar tidur (untuk tempat)

NAdj: rumah baru, rumah sederhana 
(bersifat)

$\mathrm{NN}$ : padang pasir (yang terdiri atas), buku bacaan (untuk di)

VAdj: makan besar, tidur nyenyak (bersifat)

AdjAdj: merah muda, hitam manis (bersifat)

NumN: lima hari, seratus orang (menyatakan jumlah) dsb.

Dengan melihat contoh-contoh di atas, diketahui bahwa dalam membentuk frasa umumnya disusun seperti itu, yaitu pokok yang utama atau yang diterangkan diletakkan di depan, sedangkan keterangan atau penjelasannya diletakkan sesudah unsur pokok itu. Inilah yang disebut dengan istilah hukum DM.

Dengan demikian, kita dapat melihat perbedaan antara bahasa Indonesia (juga bahasa-bahasa lain yang termasuk rumpun Austronesia) dengan bahasa yang tergolong dalam rumpun Indo-German, seperti bahasa Belanda dan bahasa Inggris, misalnya, post office (Inggris) 'kantor pos', gouverneur kantoor (Belanda) 'kantor gubernur’. Ada pula yang menanyakan apakah seorang wanita yang menjadi dokter disebut dokter wanita? Penjelasannya sebagai berikut. Wanita dokter ialah 'wanita yang menjadi dokter’, sedangkan dokter wanita ialah `dokter yang keahliannya ialah penyakit-penyakityang diderita oleh wanita '. Hal itu dapat kita bandingkan dengan dokter anak, dokter kandungan, dokter mata, dan sebagainya. Contoh lain, wanita pencuri ialah 'wanita yang suka mencuri', sedangkan pencuri wanita ialah 'orang (laki-laki atau perempuan) yang mencuri wanita`. Hal itu dapat kita bandingkan dengan wanita penipu dan penipu wanita.

Dalam bahasa Indonesia tidak selalu berlaku Hukum D-M, ada pengecualiannya. Pengecualian-pengecualian tersebut, sebagaimana diungkapkan Sutan Takdir
Alisjahbana adalah sebagai berikut.

1. Beberapa jenis kata bantu dan kata keterangan, misalnya: akan, lagi, masih, kurang, makin, lebih, terlalu, amat, sedang, sudah, dan sebagainya.

Contoh: sudah mekar: sudah (M)-mekar (D), berlaku kebalikan Hukum D-M, yakni Hukum M-D.

sangat susah: sangat (M)-susah (D), berlaku Hukum M-D.

2. Kata bilangan: misalnya sebuah, sebutir, sebiji, seutas, sebatang, sehelai, satu, dua, tiga, dan sebagainya.

Contoh: sebuah jeruk: sebuah (M)-jeruk (D), berlaku Hukum M-D (Berapa jeruk?)

tiga orang: tiga (M)-orang (D), berlaku Hukum M-D (Berapa orang?)

3. Kata depan: misalnya: di, ke, dari, atas, kepada, dan sebagainya.

Contoh: dari Medan: dari (M)-Medan (D), berlaku Hukum M-D, kebalikan Hukum D-M.

kepada saya: kepada (M)-saya (D), berlaku Hukum M-D.

Selain pengecualian-pengecualian tersebut, tidak ditemukan pengecualian yang lain dari hukum D-M. Adakalanya, untuk menghindari terjadinya penyimpangan atau pelanggaran terhadap peraturan yang berlaku (hukum D-M), gabungan dua kata yang terpisah disatukan penulisannya sehingga menjadi satu kata, misalnya, frasa pasca sarjana: pasca (M)-sarjana (D), berlaku Hukum M-D, ditulis pascasarjana sehingga tidak ada masalah Hukum D-M.

Penyebab kesalahan berbahasa seseorang dipengaruhi bermacam-macam faktor. Corder (1982:10) membedakan tiga macam kesalahan berbahasa yang dilakukan oleh penutur asli, yaitu (1) lapse, (2) error, (3) mistake. Lapse adalah 
suatu jenis kesalahan bahasa yang terjadi karena seorang pembicara berganti cara mengatakan suatu kalimat diucapkan selengkapnya dan kesalahan karena tidak disengaja (slip of the tongue atau slip of the pen). Error adalah suatu jenis kesalahan yang disebabkan oleh pelanggaran terhadap aturan tata bahasa karena seorang pembicara mungkin memiliki aturan tata bahasa yang berbeda. Sementara, yang dimaksud dengan mistake adalah suatu jenis kesalahan yang terjadi karena pembicara/penulis tidak tepat menggunakan kata atau ungkapan pada situasi yang cocok. Kesalahan berbahasa yang dibuat seseorang yang sedang dalam proses belajar bahasa kedua disebut juga error.

Pendapat lain, Taylor (1975), membedakan lima golongan kesalahan berbahasa, yaitu (1) generalisasi berlebihan, penerapan tata bahasa pada situasi yang tidak tepat, (2) transfer, pemindahan unsur-unsur bahasa pertama ke dalam bahasa kedua, (3) terjemahan, kesalahan yang mengubah jawaban yang dikehendaki, (4) kesalahan yang tidak diketahui sebabnya, dan (5) kesalahan yang tidak perlu dipertimbangkan.

Berdasarkan pemahaman yang telah dikemukakan di atas, penulis memandang bahwa kesalahan dalam berbahasa terjadi karena adanya suatu aturan atau kaidah bahasa yang diabaikan, baik disengaja maupun tidak disengaja oleh pemakai bahasa dalam pemakaian suatu bahasa. Kesalahan tersebut terjadi karena faktor interlingual, yaitu interferensi yang berlebihan bahasa pertama atau bahasa ibu terhadap bahasa target.

\section{Metode Penelitian}

Dalam penelitian ini digunakan metode deskriptif kualitatif. Penggunaan metode tersebut untuk memperoleh deskripsi mengenai hal-hal yang diteliti dan berlangsung pada masa sekarang. Penelitian ini dilakukan dengan tiga tahapan strategis, yaitu penyediaan data, analisis data, dan penyajian hasil analisis data (Sudaryanto, 1993:5).

Pengumpulan data penelitian ini menggunakan teknik observasi dan teknik catat atau rekam dalam bentuk foto (Mahsun 2005:90). Teknik ini dilakukan untuk memperoleh data secara langsung dari objek penelitian. Pengamatan dilakukan pada media luar ruang yang terdapat di lokasi penelitian. Lokasi pengambilan data di Kabupaten Bantul. Pembagian lokasi itu berdasarkan kesepakatan antarpengkaji bahasa di Balai Bahasa Daerah Istimewa Yogyakarta. Data yang diperoleh dicatat atau difoto sebagai korpus data. Pengambian data dilakukan pada tahun 2014 sampai dengan 2015. Data-data berupa foto tersebut diklasifikasi berdasarkan keunikan penyimpangannya, salah satunya dengan melihat struktur kelompok kata atau frasanya.

Seperti penjelasan sebelumnya, pola penyusunan kelompok kata atau frasa ada dua jenis, yaitu (1) inti atau induk terletak di kiri pewatas, yaitu kata yang di depan adalah kata yang diterangkan (D) dan kata yang menyertainya adalah kata yang menerangkan (M), (2) inti atau induk terletak di kanan pewatas, yaitu kata yang di depan adalah kata yang menerangkan (M) dan kata yang menyertainya adalah kata yang diterangkan (D) (Sugono, 1999). Pola penyusunan frasa dalam bahasa Indonesia mengikuti pola "diterangkan-menerangkan" (D-M), kecuali pada nama yang menjadi satu kata, seperti adikarya, artagraba, swakarsa, dan sebagainya. Hukum D-M mempunyai pengecualian antara lain, kata depan, kata 
bilangan, kata keterangan, kata kerja bantu, dan kata majemuk dari bahasa asing.

Pengertian kain rentang adalah kain yang direntangkan dan berisi slogan, propaganda, atau berita yang perlu diketahui umum. Kain rentang sebagai suatu media informasi, bisanya dibuat dengan menggunakan cat, sablon (screen printing) atau dengan cara cat mesin. Kain rentang pada zaman sekarang ini sebagai media promosi atau media iklan yang cukup populer karena harganya yang cukup murah serta proses pengerjaannya yang sangat cepat. Kain rentang sangat dibutuhkan, khususnya dalam promosi, baik itu untuk memperkenalkan maupun membuat masyarakat umum mengetahui suatu perusahaan atau produk. Melalui kain rentang juga, kita dapat menampilkan gambar sekaligus informasi yang menunjang minat pembeli atau konsumen. Oleh karena itu, kain rentang yang dipasang terkadang tidak mengikuti kaidah tata bahasa Indonesia hanya demi menarik konsumen sebanyak-banyaknya.

Selanjutnya, pengertian papan nama adalah papan yang dipasang di depan rumah atau kantor yang bertuliskan nama (orang, organisasi, lembaga, perusahaan, dan sebagainya). Papan nama merupakan jenis reklame visual terbuat dari papan kayu, lembaran logam, seperti seng atau aluminium, atau bahan keras lainnya, yang pada umumnya bertuliskan nama instansi atau perusahaan, alamat, logo, dan sebagainya. Papan nama biasanya dipasang di depan kantor atau instansi pemerintah atau swasta. Seperti halnya dengan kain rentang, pada papan nama juga masih ditemukan kesalahan dalam penulisannya.

Data yang sudah terkumpul atau data teridentifikasi dicatat dalam korpus data. Selanjutnya, data tersebut diklasifikasikan dan dianalisis berdasarkan aspek dan tipe kesalahan. Sesuai dengan karakteristik data yang ingin diperoleh, penganalisisan data penelitian ini menggunakan teknik kualitatif. Hal ini sesuai dengan karakteristik data yang akan dideskripsikan (Mahsun, 2005:90). Berkaitan dengan ini, Ellis (dalam Tarigan, 1988:68) mengemukakan bahwa langkah kerja analisis kesalahan berbahasa adalah mengumpulkan data, mengidentifikasikan data, menjelaskan kesalahan, dan mengevaluasikan.

Hasil analisis data disajikan dengan metode penyajian informal. Menurut Sudaryanto (1993:144--157), penyajian informal adalah penyajian hasil analisis data dengan kata-kata biasa walaupun dengan terminologi yang teknis sifatnya. Penyajian secara informal ini maksudnya tanpa mengunakan tanda atau lambang tertentu.

\section{Pembahasan}

Dalam pembahasan berikut akan dijelaskan beberapa bentuk pelanggaran hukum D-M yang terdapat pada spanduk dan papan di Kabupaten Bantul. Pelanggaran yang ada tersebut memiliki keunikan masing-masing. Pelanggaranpelanggaran yang unik itu dapat ditemukan pada spanduk dan papan nama, seperti hotel, toko elektronik, toko swalayan, dan rumah makan. Berikut contoh untuk spanduk dan papan nama yang tidak menggunakan hukum D-M karena mempunyai tujuan tertentu.

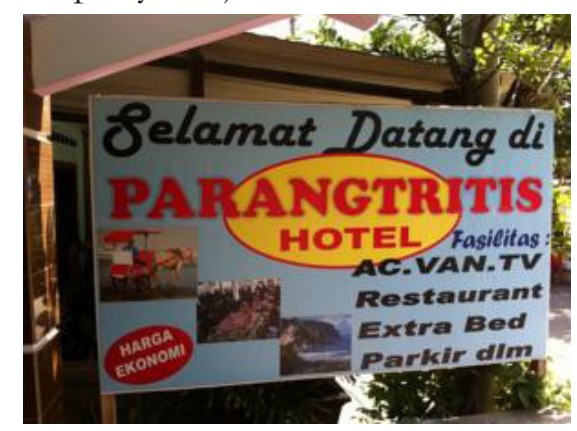


Papan nama contoh (1) tersebut terletak di tempat wisata Pantai Parangtritis, Bantul. Pada papan nama tersebut ditulis PARANGTRITIS HOTEL. Penulisan Parangtritis Hotel tidak mengikuti hukum D-M dalam bahasa Indonesia. Susunan yang benar ialah Hotel Parangtritis bukan Parangtritis Hotel. Hal tersebut disebabkan unsur pokok atau yang diterangkan adalah Hotel, sedangkan Parangtritis hanya unsur penjelas atau yang menerangkan. Di samping itu, pada papan nama tersebut masih ditemukan kesalahan diksi, kesalahan penulisan, dan kesalahan tanda baca. Pemilihan kata van juga dipertanyakan. Jika maksudnya adalah kipas angin, pilihan katanya bukan van, melainkan fan. Akan tetapi, kata fan dalam KBBI dimaknai pengagum atau penggemar. Kesalahan penulisan ada pada kata restaurant. Dalam bahasa Indonesia tidak ada konsonan rangkap $n t$ di akhir dan diftong an ditengah menjadi $o$ sehingga yang benar adalah restoran. Kesalahan tanda baca terletak pada singkatan $d l m$ yang tidak menggunakan tanda titik di akhir. Sebagai hotel kelas melati, hotel tersebut mungkin tidak terlalu memikirkan kaidah penulisannya. Hotel tersebut hanya mementingkan bagaimana cara menarik konsumen agar mau menginap dan sasarannya wisatawan mancanegara.

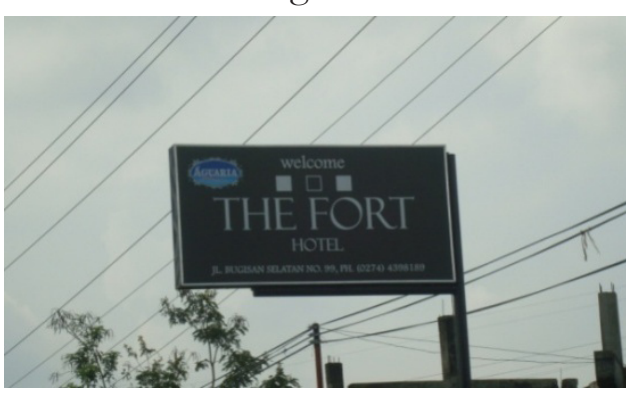

Papan nama contoh (2) tersebut terletak di Jalan Bugisan Selatan, Ngestiharjo, Kasihan, Bantul. Pada papan nama tersebut ditulis THE FORT HOTEL. Penulisan THE FORT HOTEL tidak mengikuti hukum D-M dalam bahasa
Indonesia. Susunan yang benar ialah HOTEL THE FORT bukan THE FORT HOTEL. Hal tersebut disebabkan unsur pokok atau yang diterangkan adalah Hotel, sedangkan The Fort hanya unsur penjelas atau yang menerangkan. Di samping itu, pada papan nama hotel tersebut, penggunaan kata asing sangat mendominasi. Selain nama hotel dengan bahasa asing, hal lain tampak pada penggunaan kata "welcome". Hanya nama jalan yang menggunakan bahasa Indonesia dan itu pun ditulis lebih kecil. Penggunaan bahasa asing pada papan nama sebenarnya baik untuk menarik wisatawan asing, asalkan ditulis di bawah bahasa Indonesia, misalnya "Selamat Datang di" di bawahnya ditulis "Welcome to" dengan ukuran yang lebih kecil. Sebagai hotel yang cukup besar, hotel tersebut seharusnya mengikutikaidah tata bahasa Indonesia dalam penulisan papan namanya. Pemilik hotel diperbolehkan menggunakan bahasa asing, khususnya bahasa Inggris, tetapi tidak lupa menulis bahasa Indonesianya karena dalam undang-undang sudah jelas bahwa bahasa Indonesia wajib digunakan untuk nama bangunan atau gedung, jalan, apartemen atau permukiman, perkantoran, kompleks perdagangan, merek dagang, lembaga usaha, lembaga pendidikan, organisasi yang didirikan atau dimiliki oleh warga negara Indonesia atau badan hukum Indonesia.

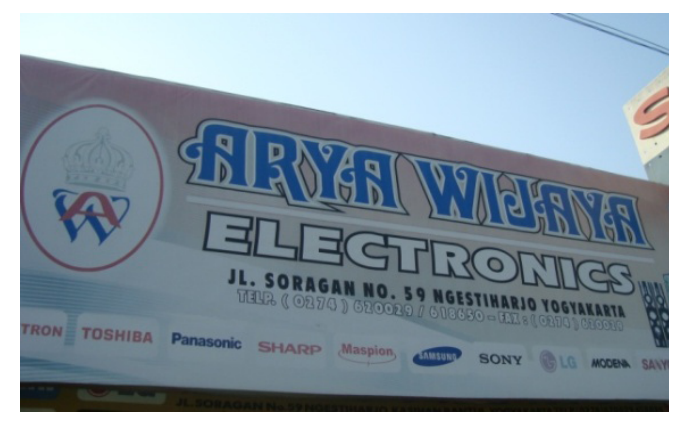

Papan nama contoh (3) tersebut terletak di Jalan Soragan, Ngestiharjo, Kasihan, Bantul. 
Pada papan nama tersebut ditulis $A R Y A$ WIJAYA ELECTRONICS. Penulisan ARYA WIJAYA ELECTRONICS tidak mengikuti hukum D-M dalam bahasa Indonesia karena yang dipilih istilah asing, yaitu bahasa Inggris. Dalam bahasa Indonesia istilah electronics telah disesuaikan penulisannya menjadi elektronik yang maknanya 'alat yang dibuat berdasarkan prinsip elektronika'. Itu berarti alatnya bukan sebuah toko. Dengan demikian, istilah yang lebih tepat ialah toko elektronik sehingga susunannya menjadi TOKO ELEKTRONIK ARYA WIJAYA bukan ARYA WIJAYA ELECTRONICS. Hal tersebut disebabkan unsur yang diterangkan ialah TOKO ELEKTRONIK, sedangkan ARYA WIJAYA hanya unsur penjelas atau yang menerangkan.

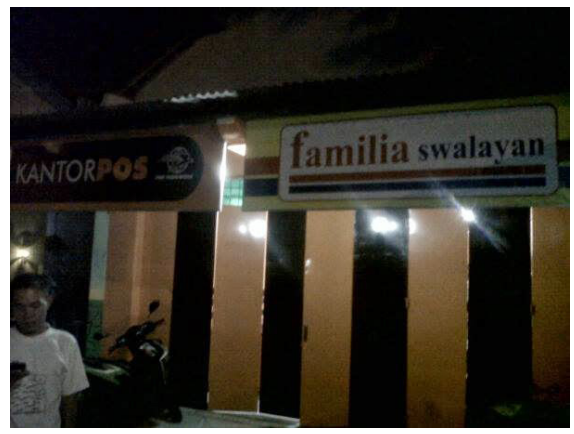

Papan nama contoh (4) tersebut terletak di Jalan Bantul Km 8.5 atau Dusun Cepit, Pendowoharjo, Sewon, Bantul. Pada papan nama tersebut ditulis familia swalayan. Penulisan familia swalayan tidak mengikuti hukum D-M dalam bahasa Indonesia. Susunan yang benar ialah swalayan familia bukan familia swalayan. $\mathrm{Hal}$ tersebut disebabkan unsur pokok atau yang diterangkan adalah swalayan, sedangkan familia hanya unsur penjelas atau yang menerangkan. Di samping itu, pada papan nama tersebut menggunakan huruf kecil semua. Sebaiknya pada huruf awal digunakan kapital sehingga menjadi Swalayan Familia. Di samping toko swalayan, ada papan nama bertuliskan kantor pos. Kantor pos dapat dianggap sebagai penerjemahan dari kata post office. Dalam hal ini, masyarakat lebih memilih menggunakan istilah kantor pos daripada post office. Penyebabnya kemungkinan istilah kantor pos telah ada sejak dahulu, berbeda dengan kata swalayan yang belum lama.

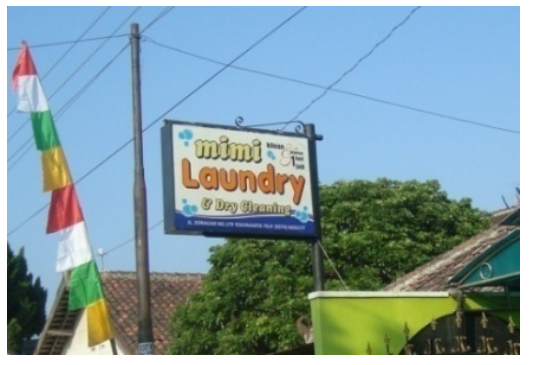

Usaha pencucian baju ini memang tergolong usaha baru sehingga istilahnya pun masih menggunakan istilah asing. Penggunaan kata laundry dapat dipahami karena kata tersebut lebih dikenal di masyarakat. Papan nama contoh (5) tersebut terletak di Jalan Soragan, Ngestiharjo, Kasihan, Bantul. Pada papan nama tersebut tertulis mimi Laundry. Penulisan mimi Laundry tidak mengikuti hukum D-M karena memang laundry tidak ada dalam bahasa Indonesia. Agar penulisannya dapat sesuai dengan kaidah bahasa Indonesia, kata laundry sebaiknya diganti dengan penatu. Dengan demikian, penulisannya menjadi Penatu Mimi dan di bawahnya baru dapat ditulis Mimi Laundry dengan huruf yang lebih kecil.

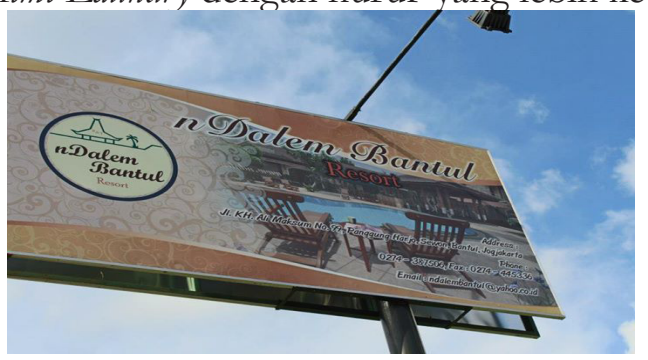

Papan nama contoh (6) tersebut terletak di Jalan K.H. Ali Maksum No. 99, Panggungharjo, Sewon, Bantul. Pada papan nama tersebut tertulis nDalem Bantul Resort. Penulisan nDalem Bantul Resort tidak mengikuti hukum D-M 
karena yang dipilih bahasa asing. Dalam bahasa Indonesia istilah Resort telah disesuaikan penulisannya menjadi Resor yang maknanya 'daerah kecil'. Dengan demikian, susunan yang benar ialah Resor nDalem Bantul bukan nDalem Bantul Resor. Hal tersebut disebabkan unsur pokok atau yang diterangkan adalah Resort, sedangkan nDalem Bantul hanya unsur penjelas atau yang menerangkan. Di samping itu, pada papan nama tersebut masih digunakan kata asing, seperti Resort. Jika tetap ingin menulis istilah asingnya, istilah asing tersebut dapat ditulis di bawah bahasa Indonesia.

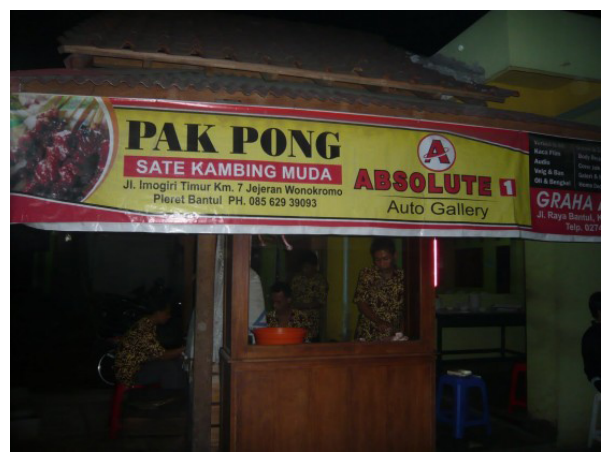

Spanduk tersebut berbeda dengan spanduk kuliner pada umumnya. Spanduk kuliner biasanya menyebut produk dahulu, setelah itu baru menyebut makanannya, misalnya Gudeg Yu Djum, Bakpia Pathok 75, Geplak Mbok Tumpuk, dan sebagainya. Spanduk contoh (7) yang terletak di Jalan Imogiri Timur Km 7 atau Dusun Jejeran, Wonokromo, Pleret, Bantul ini struktur katanya terbalik. Pada spanduk tersebut ditulis PAK PONG SATE KAMBING MUDA. Penulisan PAK PONG SATE KAMBING $M U D A$ tidak mengikuti hukum D-M dalam bahasa Indonesia. Susunan yang benar ialah SATE KAMBING MUDA PAK PONG bukan PAK PONG SATE KAMBING MUDA. Hal tersebut disebabkan unsur pokok atau yang diterangkan adalah SATE KAMBING MUDA, sedangkan $P A K$ PONG hanya unsur penjelas atau yang menerangkan. Dalam spanduk ini, pemiliknya mungkin ingin lebih menonjolkan Pak Pongnya daripada satai kambing mudanya. Dalam hal ini dapat dimaklumi sebab merek Pak Pong ini telah menjadi merek satai yang terkenal, khususnya bagi pengemar satai klathak (satai yang ditusuk menggunakan ruji).

Dari ketujuh contoh di atas, kita dapat melihat penyimpangan masing-masing. Contoh (1) dan (2) terdapat kemiripan. Untuk penamaan hotel, pemilik lebih menekankan nama hotelnya sehingga nama hotel ditulis terlebih dahulu, baik hotel kecil maupun hotel besar. Tujuannya dapat dipastikan untuk menarik konsumen yang dalam hal ini wisatawan mancanegara. Contoh (3) terdapat penyimpangan pada kata elektronics-nya. Pemilik mungkin beranggapan electronics bermakna 'toko elektronik' sehingga memberi tokonya nama ARYA WIJAYA ELECTRONICS. Padahal, jika diartikan, elektronik dalam bahasa Indonesia bermakna 'alat yang dibuat berdasarkan prinsip elektronika' bukan toko. Pada contoh (4), penyimpangannya terdapat dalam perbandingan antara familia swalayan dan kantor pos. Masyarakat sudah sangat akrab dengan kata kantor sehingga tidak membalik susunannya. Hal itu berbeda dengan kata swalayan yang dianggap baru. Contoh (5) terdapat penyimpangan pada kata laundry. Kata laundry sebenarnya belum diserap ke dalam bahasa Indonesia, tetapi telah digunakan secara meluas di masyarakat. Dalam bahasa Indonesia, istilah yang tepat ialah penatu. Akan tetapi, istilah ini malah kurang dikenal di masyarakat sehingga pemilik lebih memilih istilah laundry. Contoh (6) terdapat penyimpangan dalam kata resort. Kata resort sebenarnya sudah diserap ke dalam bahasa Indonesia menjadi resor, tetapi pemilik masih memilih menggunakan istilah resort demi 
gengsi nama kompleks perumahan. Contoh (7) penyimpangan terdapat pada kata Pak Pong. Kebiasaan yang ada, nama kuliner itu ditulis dahulu, baru diikuti nama warung atau tokonya. Pemilik mungkin beranggapan bahwa kata Pak Pong lebih komersial daripada sate kambing muda sehingga susunannya dibalik menjadi $P A K$ PONG SATE KAMBING MUDA.

\section{Simpulan dan Saran}

Berdasarkanhasilpemantauan yang dilakukan oleh penulis berkaitan dengan rumusan masalah dalam penelitian ini, ada beberapa hal yang dapat disimpulkan, yaitu (1) kesalahan itu terjadi dalam upaya untuk menarik perhatian konsumen atau masyarakat, (2) kesalahan itu terjadi karena istilah yang digunakan dianggap lebih bergengsi, dan (3) kesalahan itu terjadi disebakan pemakaian kata tersebut lebih umum di masyarakat. Khusus untuk nomor (3), kata atau istilah asing yang telah dikenal di masyarakat secara luas sebaiknya diserap ke dalam bahasa Indonesia dengan ejaan yang disesuaikan, misalnya kata laundry. Dalam Kamus Besar Babasa Indonesia (KBBI), istilah laundry tidak ditemukan. Istilah yang ada dalam KBBI ialah penatu, dobi, atau benara. Akan tetapi, ketiga istilah tersebut kurang dikenal di masyarakat. Masyarakat lebih sering menggunakan istilah laundry. Untuk itu, istilah laundry sebaiknya diserap ke dalam bahasa Indonesia, misalnya dengan penyesuaian ejaan mejadi laundri.

Selain itu, undang-undang yang ada tidak memberikan sanksi jika aturan tersebut dilanggar sehingga masih banyak spanduk dan papan nama yang tidak memenuhi aturan yang ada. Mereka, para pemilik modal, beranggapan bahwa penggunaan bahasa asing, khususnya bahasa Inggris lebih menguntungkan dari segi
pemasaran.Oleh karena itu, penulis berharap agar Pemerintah Kabupaten Bantul melakukan sosialisasi Undang-Undang Republik Indonesia Nomor 24 Tahun 2009 tentang Bendera, Bahasa, dan Lambang Negara, serta Lagu Kebangsaan, yang di dalamnya memuat aturan atau ketentuan tentang penggunaan bahasa Indonesia yang baik dan benar di tempat umum, khususnya nama bangunan atau gedung, jalan, apartemen atau permukiman, perkantoran, kompleks perdagangan, merek dagang, lembaga usaha, lembaga pendidikan, organisasi yang didirikan atau dimiliki oleh warga negara Indonesia atau badan hukum Indonesia. Selain itu, Pemerintah Kabupaten Bantul diharapkan untuk melakukan upaya penertiban penggunaan bahasa Indonesia di tempat umum dan membuat peraturan daerah (perda) tentang penggunaan bahasa Indonesia di tempat umum, serta memberi sanksi administratif kepada pihak terkait yang tidak menaati aturan yang berlaku.

\section{Ucapan Terima Kasih}

Penelitian ini tidak akan selesai tanpa ada bantuan dan dukungan dari berbagai pihak. Untuk itu, penulis mengucapkan terima kasih yang setulus-tulusnya kepada Dr. Widjajanti selaku pembimbing dalam penelitian ini. Selain itu, penulis juga mengucapkan terima kasih kepada Bapak Tirto Suwondo selaku Kepala Balai Bahasa Daerah Istimewa Yogyakarta yang telah mengizinkan penulis mengikuti Diklat Jabatan Fungsional Peneliti Tingkat I di LIPI, serta teman-teman peserta Diklat Jabatan Fungsional Peneliti Tingkat I Gelombang IX atas dukungannya selama proses pembuatan penelitian ini. 


\section{Daftar Pustaka}

Alwi, Hasan et al.. 1992. Bentuk dan Pilihan Kata. Jakarta: Pusat Pembinaan dan Pengembangan Bahasa.

1998. Tata Babasa Baku Bahasa Indonesia. Jakarta: Balai Pustaka.

Alisjahbana, S. Takdir. 1983. Tatabahasa Baru Babasa Indonesia (Cetakan ke-44). Jakarta: Dian Rakyat.

Corder, S. Piet. 1982. Error Analysis and Interlanguage. Oxford: Oxfod University Press.

Mahsun. 2005. Metode Penelitian Bahasa. Jakarta: Raja Grafindo Persada.

PusatBahasa,Departemen Pendidikan Nasional. 2005. Pedoman Umum Ejaan Bahasa Indonesia yang Disempurnakan. Jakarta: Balai Pustaka.

2007. Pedoman Umum Pembentukan Istilah. Jakarta: Balai Pustaka. 1997. Pedoman Umum Pembentukan Istilah. 1997. Jakarta: Pusat Bahasa.

Ramlan. 1985. Tata Babasa Indonesia: Penggolongan Kata. Yogyakarta: Andi Offset.

1986. Imu Bahasa Indonesia: Sintaksis. Yogykarta: CV Karyono.
Sudaryanto. 1993. Metode dan Aneka Teknik Analisa Bahasa: Pengantar Penelitian Wabana Kebudayaan secara Linguistik. Yogyakarta: Duta Wacana University Press.

Sugono, Dendy (Penyunting Utama). 2006. Buku Praktis Bahasa Indonesia 1. Jakarta: Pusat Bahasa, Departemen Pendidikan Nasional.

2009. Pengindonesiaan Kata dan Ungkapan Asing. Jakarta: Pusat Bahasa, Departemen Pendidikan Nasional.

Tim Penyusun Kamus Pusat Bahasa. 2008. Kamus Besar Bahasa Indonesia. Jakarta: Gramedia Pustaka Umum.

Taylor,B.P.1975.“'TheUseof Overgeneralization and Transfer learning Strategic by Elementary and Intermediate University Student Learning ESL", dalam Language Learning, Vol.25, 1975 (1), hlm. 73--107, Washington DC: TESOL.

Verhaar, Y.W.M. 1996. Asas-Asas Linguistik Umum. Yogyakarta: Gadjah Mada University Press. 